\title{
Editorial: Tax policy and pensions
}

At one time pension schemes were almost purely a creature of tax legislation. Almost all pension funds were unfounded in the UK until 1921, and pensions paid almost at the whim of the employer as a reward for long service. Indeed, it was not until the 1970s in the UK that preservation (vesting) was introduced as a concept so as to protect those who left the employer before retirement. Until then, if you left employment before retirement, you lost your pension. It was the first real piece of consumer protection legislation, and something of an aberration in the thicket of tax law on pensions.

The reason for the need for the change in tax law in 1921 was that while it had been recognised by the courts in the 19th century that it was within the powers of companies to pay salaries to retired former employees as an expense of running the business (wholly and necessarily incurred), pre-funding the pension 'obligations' was not deductible. It took pressure from the predecessor of the National Association of Pension Funds (NAPF) to change the law, so that if the company went bust, there might be something in the kitty to pay pensions to long-serving employees.

Plus ça change. Now pre-funding is not only permitted, it is, by virtue of the minimum funding requirement, required. Moreover, the requirement is one of the many causes leading to the dismantling of one of the jewels in the UK pensions crown, the defined benefit (DB) pension scheme.

That jewel may be rediscovered in due course, albeit somewhat recut. But one of the other reasons for the decline in provision of company pensions was undoubtedly the tax regime, developed over 80 years into an unwieldy and complex superstructure that was expensive to administer, costly to apply and frequently counterproductive as so much regulation is.

Now the UK Inland Revenue has proposed, with every chance of success, a complete recasting of the tax structure as it applies to pensions. And with some obvious exceptions it looks like a return to basic principles (a dangerous but nonetheless useful phrase) with simplification at its heart. The Inland Revenue in a uniquely collaborative exercise with the Treasury and the Department for Work and Pensions (DWP) issued a consultative document (and other bits of paper) alongside the DWP's Green Paper. It had a poor omen; for a simplification exercise, the publication of ten different bits of paper with a wide variety of typographical influences boded ill. There were press releases, technical annexes and other documents in no particular order.

But on reflection it now seems to be one of the Inland Revenue's better efforts (it is having a bad time in the press at present on other fronts), showing occasionally at the joins where political compromises have been negotiated, but with a strategic theme, perhaps the first for 70 years in fiscal thought as applied to pensions. It broadly follows a very simple principle, explored some years ago in an NAPF 
paper (Tax Simplification Report:

Making Pensions Easy, 1998) that all contributions should be tax deductible, that all growth within pensions should be tax free, and that (lump sums excepted) all benefits should be annuitised and taxable. In its pure form this follows the EU/OECD

recommended pensions tax system, known to those in the game as EET (Exempt, Exempt, Taxed), and provides a fiscal neutrality that pensions need for their own stability and to give the public some degree of trust in the system.

The new system is due to come into play by mid-2004, and while if implemented as it stands (or even if slightly modified) would not act as an incentive to save through pensions, it would at least not act as a disincentive, as the present system does. By reducing the present (at least) eight different tax regimes to one, and ensuring that that one is simple and straightforward, the reforms should result in a truly huge saving in administration and computer software costs for pension schemes and their managers. In time we will all learn to forget what an AVC, an FSAVC or an earnings cap was and what the problems of retained benefits and transfer limits were. It will mean the destruction of around 1,300 pages of Inland Revenue rules to be replaced by around 25 pages of tax law, probably drafted in English along the lines of the principles set out in the Tax Law Rewrite Project. It is a tremendous advance.

It has its compromises. First, it limits the maximum value of pension benefits to $f 1.4 \mathrm{~m}$. For the majority of the population this is anyway in excess of their maximum expectations. Secondly, it limits maximum contributions ('inflows of value') in any one year to $£ 200,000$. The lump-sum maximum is increased in most cases. The retirement rules are mostly destroyed (so why persist with the Venables case?) although pension cannot be taken until age 55 .

There are some unknowns. Some of the details on the transitional arrangements need to be spelt out, and there will be a few (very few) losers, although those that are will not be happy. Even so, my colleague Alastair Meeks has done some number crunching and come to the rather surprising conclusion that although any funds in the pot over the $\mathcal{K}_{1.4 \mathrm{~m}}$ will be taxed at over 30 per cent, it will in most cases still make more sense to contribute to a pension than to any other form of saving. The retention of the annuity requirement (with some minor relaxations) shows that pressure groups do not always get their own way, especially when they are wrong in principle. There are still issues to be explored in relation to unfunded arrangements (although FURBS are expected to die, as are SSASs, at least as far as loanbacks are concerned) and relationships with overseas arrangements (following recent EU court decisions), and all the rather foolish rules on surplus now go.

There are some rather (fiscally) pointless restrictions. The $£ 1.4 \mathrm{~m}$ and $£ 200,000$ limits will cause added administration in due course and are really unnecessary (except for cosmetic reasons and for reasons of internal polity). The reinvention of more caps is unnecessary to protect the interests of the Revenue and the Exchequer and will contribute to more tax planning and schemes to avoid the controls. One is already around; it has been suggested by PricewaterhouseCoopers that spouses could be put on the payroll at $\mathcal{K}^{1}$ a year, but have (in small ownercontrolled companies at least) contributions made on their behalf. 
That would get the contributions up to $2.8 \mathrm{~m}$ within the controls, and enable better pensions (ie based on single lives) to be paid. There will be other opportunities as the scheme begins to be better understood. If the Revenue learn to be relaxed about these opportunities (in the end they will get their tax back) there could be a modest improvement in the provision of pensions. The obsessive control on 'fatcat' pensions has been one of the reasons for the fall in provision of pensions for slightly slimmer cats.

As yet we have not been shown the actual legislation (the devil is very often in the detail, and there could be quite a deal of detail). And it is only in practice that we will know whether the flood of Pensions Updates from whatever branch of the Inland Revenue is deputed to supervise the regime will diminish. The good news is that there is a determination to draft these rules in modern English style (following the Tax Law Rewrite Project style), and in short form, so it may be that we shall begin to see the emergence of that dreaded continental invention, legislation by principle.

But it is a brave and noble effort of the Inland Revenue and the Treasury; it shows that government departments really will listen if there is a good case put to them; it should and could form the basic building block for a resurgence and renaissance in pension provision in the country. The accompanying Green Paper on simplification of the Pensions Act by way of contrast is a rather less adventurous affair, paying lip service to the Pickering proposals, but lacking equivalent courage (understandably in the light of recent press coverage) in removing swathes of the knee-jerk legislation that emerged following Maxwell. Intriguingly we will have a new consolidating Pensions Act perhaps in 2004, giving less than the usual decade between such legislation. And neither proposals of course can deal with the pernicious FRS17 or son of FRS17; the Accounting Standards Board and International Accounting Standards Boards are examples of those organisations which have been described as having powers without responsibilities; their corporate governance is deeply wanting and there are few government proposals to control their arbitrary rule-making.

It is a useful time for the Inland Revenue and the government as a whole to review the roles of tax in pensions. As mentioned, at one time tax policy was critical in the design of schemes indeed tax supervision acted also as consumer supervision. Now tax is only one of a host of factors in the design of schemes, including social security, consumer protection, regulation and compliance and accounting rules. The reduced role of tax, at a time when the tax savings by contributing to pensions is much less than in the 1970s (when tax rates were at least 60 per cent and sometimes over 100 per cent) is something to be welcomed; but it raises issues of whether the tax breaks given to pensions are superior (as they should be for alienated funds) to other forms of arrangements such as savings. The increasing lack of distinction between pensions and savings is deeply unsatisfactory. The reasons for a special tax break (in fact a simple fiscal neutrality, not a real break, despite the perverse conclusions of the Treasury statistics) is that individuals need some kind of reason to alienate their income and then sacrificing its return in exchange for annuity, rather than putting it under the bed. The problems of ACT recovery, increases stamp duty costs and attacks on share redemptions, as well as the decisions in Venables $v$ Hornby (Court of Appeal 2002) all indicate to employers 
and employees that pensions are not something that the government wishes to support or approve of, despite wordy assurances to the contrary. And indeed the Treasury is very ambivalent about pensions. In truth, they would rather they did not exist. The fact that pension agglomerations have proved a major source of capital in a capitalist economy, compared for example with the French who have always had problems finding capital, does not seem to attract the Treasury. Nor does the Treasury have any problem in finding pensions for its own; the recent furore about the Lord Chancellor's pensions is just one example. If the country is really keen to ensure that private pensions form part of the financial armoury of most UK citizens, it will have to remove more of the disincentives to pension provision. There is no need, as some observers suggest, to introduce incentives. The worry about old age is strong enough. But that is no reason to offer other savings systems a better deal than pensions, especially where they involve less commitment by the subscriber.

If it emerges that these new tax principles are acceptable to the industry and the population as a whole, it may be that the system may have an impact elsewhere on fiscal legislation. And if it manages to bed down with a minimum of fuss, and there are not too many abuses (there will inevitably be some, but probably not disproportionately large, and manageable within the context of the tax arrangements for pensions) and if the details are not expanded with probably inevitable regulation and practice notes from a reformed Inland Revenue pensions office, we will all learn to live with it. If we manage to get it right and we might - it may also be that the UK becomes an acceptable base for pension provision in competition with other jurisdictions such as Luxembourg or Ireland.

Robin Ellison

Editor 